DOI: https://doi.org/10.47405/mjssh.v6i6.830

\begin{tabular}{|c|c|}
\hline 4 & Malaysian Journal of Social Sciences and Humanities (MJSSH) \\
\hline $\begin{array}{l}\text { Malaysian Journa of } \\
\text { Social cciences and }\end{array}$ & Volume 6, Issue 6, June 2021 \\
\hline (MJ-sSH) & e-ISSN : 2504-8562 \\
\hline & $\begin{array}{l}\text { Journal home page: } \\
\text { www.msocialsciences.com }\end{array}$ \\
\hline
\end{tabular}

\title{
Parenting Styles of The Kadazandusun Community in Rural Areas of Sabah in Ensuring Child's Success in School
}

\author{
Rosy Talin' ${ }^{1}$, Sabariah Shariff ${ }^{1}$, Soon Singh Bikar Singh ${ }^{1}$, Prescylla Kiok ${ }^{1}$ \\ 1Faculty of Psychology and Education, Universiti Malaysia Sabah (UMS) \\ Correspondence: Rosy Talin (rostalin@ums.edu.my)
}

\begin{abstract}
Today, many KadazanDusun children who live in rural areas, whose parents are without educational background and earn a living as farmers, have successfully entered public tertiary level education institutions (IPTA) or private tertiary level education institutions (IPTS). This development has prompted this study to identify the parenting styles involved in ensuring the success of children in school and thus succeeding in furthering to tertiary level. For data collection, this study choses the qualitative approach. Thus, to obtain the required data, interviews were carried out with parents who have more than one child studying at IPTA/IPTS, self-employed in their hometown and had no opportunity to formal education. The respondents were chosen through purposive and snowball selection. The findings show that both authoritarian and authoritative parenting styles are practiced by the KadazanDusun parents in ensuring that children are successful in school. The children who were also interviewed agreed these styles are practiced because of the difficulties in the parents' lives due to the lack of good education. Therefore, the parents want to ensure their children to succeed in their education for a better future. The parents do not want their economic problems which they are facing now to be inherited by their children.
\end{abstract}

Keywords: parenting styles, authoritarian styles, authoritative styles, rural education, child's success in school

\section{Introduction}

This research studied the KadazanDusun community in Sabah, Malaysia specifically in terms of education aspect. An overall look of the early years of independence, the educational awareness of the KadazanDusun community is very low. This is due to the lack of information received on the importance of education for children as most KadazanDusun lived in the rural areas as well as suburbs of Sabah. The early education received by the community was first introduced by Christian missionaries who built mission schools in the main towns. Only those who lived near the towns were to have access to education. Those who were living in the rural areas or suburbs were at a disadvantage due to factors such as distance, motivation, encouragement and difficult living.

The situation has currently improved. Although most of the KadazanDusun community still live-in rural areas, work as farmers, socially and economically lagged behind, their awareness towards the importance of education for children has increased. The community are more willing to ensure their children achieve higher education. As cited in Moon \& Bouchey (2017), a qualitative study interviewing college students who were from families in which the parents did not have a college 
degree indicated that parents' expectations and beliefs regarding their child's capacity for higher education was one of the strongest factors enabling youth to break the intergenerational cycle of lower educational attainment. As a result, many children from the KadazanDusun community are employed with well-paid jobs and hold high positions in both the private and public sectors. The ability of the parents to guide their children to succeed is require to be studied so that it may served as a guide to all KadazanDusun parents in the efforts to improve the educational level of their children in the future. According to Leon-del-Barco et al. (2019), parenting styles have been used to explain the effects of family socialization on children's learning skills. Hence, there two purposes of this study. Firstly, to explore the parenting styles practiced by the KadazanDusun parents who live in rural areas and are self-employed but have children that are successful in the pursue of education in private or public tertiary education institutions. Secondly, to identify the reasons behind the parenting styles adopted.

\section{Research Literature}

Parenting style, or the knowledge of "how-to" in raising children, is a concept that originated from development psychology (Zhang, Qin \& Zhou, 2020). Baumrind (1966) has proposed a parenting style model which was introduced as the Baumrind Model. According to the Baumrind Model, there are three types of parenting styles which are the authoritative style, authoritarian style and permissive style. This model has been widely applied in studies among school students. On the other hand, Maccoby \& Martin (1983) introduced four types of parenting styles namely the authoritative style (democratic), authoritarian style (control), permissive-indulgent style (more control-free) and permissive-neglectful style (less control-over). In fact, the four parenting styles proposed by Maccoby $\&$ Martin are the result of the expansion of Baumrind's Parenting Style Model. For this study, the three parenting styles which are authoritative, authoritarian and permissive were formed based on two indiced of Baumrind (1971) which are demand index (demandingness) and responsive index (responsiveness) are used as themes for parenting styles. Parenting style refers to the behavior practiced by the parents to guide their children into becoming a successful and productive person (Razali \& Razali, 2013). The three parenting styles are explained as below.

\section{Authoritative style}

Parents who practice this parenting style monitor and improve their children's behavior in addition providing support and love (Baumrind, 1991, 1971). The authoritative style can make children behave positively (Yahaya \& Latif, 2005) because the parents ensure that the children follow the rules as well as giving the childr en autonomy. This show the parents value their children's perspective, allowing them to make choices and support their views on family matters (Bersg, 2011; Zupancic, Podlesek, \& Kavcic, 2004). This parenting style is said to be the perfect style to be practiced by every family regardless of ethnic differences.

\section{Authoritarian style}

This parenting style is the opposite of the previous parenting style. Parents who adopt the authoritarian style require the children to obey their instructions but in a less affectionate manner. Children are not given the opportunity to defend themselves. The parents do not allow children to voice their opinions and set a standard that the children must meet (Zupancic et al, 2004). Success is prioritized and is without any considerarion of the children. This parenting style does not foster the children's development (Bersg,2011). It is characterized to be using an excessive amount of power (Lazar, et al., 2009).

\section{Permissive style}

This parenting style is very tolerant. The permissive parenting style refers to friendly and supportive parents but soft in terms of control. As a result, children are not expected to contribute anything (Bergs, 2011), and are too dependent on their parents (Yahaya \& Latif, 2005). According to Santrock (2004) the children find their parents to prioritise their own matters more than the children's. The main 
features of this parenting style are few demands for house-hold responsibility, obedience and orderly behavior, which as a result are usually associated with children being less self-reliant, explorative, and self-controlled in comparison with their peers, raised within a different parenting style (Lavric \& Naterer, 2020).

Most of the existing literature has shown that parents' educational background, occupation and income will affect children's initial endowment, education investment and cultural environment (Yang \& Zhao, 2020). Based on this Parenting Style Model, domestic or international past studies such as Woofolk (1995), Othman, Azman \& Mohd Ali (2008), and Chan \& Koo (2010) found out the parenting styles, which are authoritative, authoritarian and permissive, had an impact on the child's academic achievement. A research done by Samina and Almas (2015) shows that authoritative style has a significant correlation with the children's academic achievement. While authoritarian style has a negative correlation with academic achievement. The same goes to a research by Odongo, Aloka and Raburu (2016) which shows that authoritarian style contributes to low academic achievements while the authoritative style contributes good academic achievements. A research by Ismail, Lukman dan Hamsan (2008) also states that children raised in families that practiced the authoritarian styles have moderate academic achievements. On the other hand, permissive parenting style has a low correlation with children's academic achievements. Kosterelioglu (2018) still shows that authoritative style has an impact on children's academic achievement. This finding is consistent with previous findings that have also proven that authoritative styles are positively associated with high achievement (Abar, Carter, \& Winsler, 2009; Watabe, 2011 cited in Monika \& Asudani, 2013).

\section{Methodology}

This study uses a qualitative approach. The selection of informants was done by purposive and snowball selection. Purposive selection refers to the selection of informants that meet the criteria set which are parents with more than one child studying in IPTA/IPTS, self employed in their hometown, have no contact with the outside community and did not attend higher level education school during their youth. These criteria are required to minimize external factors that may influence the parenting styles practiced. However, the snowball selection is done by acquiring suggestions from the first or previous informants of people they may know who meet the required criteria. This method helps in finding the right informant and is time saving. Other than parents, the children are also interviewed to gain access to their personal experience under their parents' parenting.

This study was carried out in several rural areas of Sabah with the majority of the population being KadazanDusun.

Commonly, the qualitative data collection methods are observations, interviews, and document analysis. However, this study used only the interview method. This method was the only one chosen due to the following constraints;

\section{Level of Education}

Based on the criteria described above and also based on the pilot study, the informants of the study were unfamiliar with letters or numbers and have very low-level reading skills. Therefore, the data required could not be obtained through questionnaires.

\section{Lack of Language Skill}

Since the criteria set on no higher education qualifications, the informants are not fluent in the Malay language or the English language. The informants are very fluent in their native language which is the KadazanDusun language. Thus, interviews using the KadazanDusun language are the most suitable data collection technique for this study. There are, however, KadazanDusun parents who were able to converse in Malay, but they find it harder to express their opinions compared to when using their own native language (KadazanDusun) to answer. 
This technique was once done by Robinson, Md. Idris, and Jiloris, (2004). The technique was done in one of their study regarding the dissatisfaction of rural patients with the health treatment against TB (tuberculosis) disease that was spread among Sabahan during that period. The interviews were conducted in the native language. The same technique was also used by Mohd. Fauzi, Nor Aini, Madeline, and Faridah (2006) in their study on the poverty rates among indigenous people in Malaysia where $86 \%$ of the population had never been to school and did not speak fluent Malaysian.

The type of interview conducted in this study was unstructured where the interviewer asks questions spontaneously. Open-ended questions are used to allow more flexibility and less pressure on the informants as it can create a casual conversation like interview. Each interview was recorded with the permission of the informants.

The data collected is transcribed and interpreted, proofread to identify the desired keywords and returned to the informants for approval. After this process is done, only then another informant be interviewed. After each interview, the same process is repeated until the data collected is enough to complete the study. The process of data collection will be stopped when the data reach a saturation level, which is when the same data is constantly obtained from the respondents although from different areas.

After completing the data collecting process, a thorough analysis (Within Case Analysis) is carried out by identifying holistically the categories that existed from all the data which is from both the informants and their children. Next, a cross-sectional analysis was carried out (Cross case Analysis). In this analysis, the categories obtained from the data of the informants will be compared to find the appropriate theme to answer the research questions.

\section{Results}

After the Cross-case Analysis was conducted on all the data from each informant, it is found that there were two parenting styles that are practiced.

\section{Authoritarian}

The research data shows that five out of ten informants use authoritarian parenting style as their primary means of ensuring their children succeed in education. These informants admitted to being strict. They would scold their children for not obeying rules, making mistakes in homework's, not wanting to go to school, not wanting to study at home, and for playing or watching TV too much. The most common punishments of the parents obtained from the data are caning, flicking, knocking the head, pulling the ear, pinching, not allowing to eat and to assign work in their farm. According to a study by Chong \& Yeo (2018) parents punishing is a common phenomenon in Malaysia.

"I'm not the type of person to be nice.. I'm very strict! Ha ha ha. They do not want to go to school, I'll punish! I don't care if they're grown or not" (Kinol, Int 13:86, 88)

"If they can't write.. I'll hit their fingers! Ha ha. When I asked them back "do you want to write?".. "yes" because they'll be scared.. I do admit my habits. I am strict towards my child." (Matri, Int 3:118, 120-121)

"Yes. Boys are stubborn and hard to be adviced. Girls are easy. Knock the boys' head and they still won't listen. If i am fed up,i do knock their heads. We scolded them.. we'll said to them "Aren't you jealous of them who work" that's how we tell them." (Sunny, Int 1: 134, 137-138, 225261) 
Data obtained from the children also shows that their parents were strict. If they were to fail to obey their parents, they would be disciplined and punished.

"Sometimes..emm.. I haven't told you yet.. my mother, right? She will teach me.. this is line.. then I couldn't follow, right? My mother will.. be angry..he he he.. pulled my ear. If the boys, knock on the head." (Mimi, Int 2:467-469)

"If we had an exam, if I have a subject that I am not so good in, my mother would scold and punish me. I've already studied hard." (Ryan, Int 20:30-31)

"Ya. Until my behind is red, until I cry because it hurts" (Ryan, Int 20:38)

"ha ha ha! That's why.. I still remember that time, Our younger sibling hasn't been schooled yet. It was my older brother and me.. but I can't remember when.. definitely about school.. If we didn't study, my mother won't let us eat! Ha ha ha.. because of not studying. My brother and I then cried and took our books. Then.. "Enough" I said and took my books and studied, only then we were fed. Ha ha ha.. that's how it goes!" (Rendi, Int 18:126-128, 130-132)

However, the data indicates the children understand that their parents are acted like that for their own good in the future.

"Don't you be like us. They will keep giving us advices to motivate us." (Mimi, Int 2: 94-98)

"The purpose of them punishing us is to make us realized not to play while studing and not be naughty." (Ryan, Int 20:38, 40, 42-43)

"They will be angry.. so let them be angry. They want me to succeed.. emh.. they want to see me succeed in my life! That's why they scolded me. For my own good." (Dina, Int 4:96, 98-99)

\section{Authoritative}

The research data showed that there are two informants who practiced the authoritative style completely. They do not prefer to be strict in their parenting with their children. If a child is being stubborn, they would approach gently. These informants believe that if a child is being scolded too often, they would gradually be less likely to obey.

"Of course not! My experience.. my child.. if they don't go to school, I will scold them...nothing serious. If I was too serious, maybe the child won't do it.. hm.. If we want to ask our children to go to school, no need to be angry.. if we are always angry, the children will not want to listen.. If we were to scold, don't be too serious.. smile a little.. hahahaha." (Rara, Int 9:290-291, 293-295, 297)

"If to be angry, not really that much. Better to joke around a little with them. Laugh a little.. hahaha.. ya.. like how we laugh with each other.. something like talk to them and joke at the same time. They might have a tantrum. But not that old-fashioned, not everyone is able to not scold, right?" (Neiry, Int 14:264-267, 271, 273) 
This informant also does not put much pressure on their children to study. They believe their children should have time to both play and learn.

"Sometimes they study and there is a time for them to study and for them to play, something like that." (Rara, Int 9:166-167)

"I don't really think to ask them to study because my child studies hard. I watch them coming home from school, study, school, study." ( Konis, Int 5:173-175)

Data from the interview conducted with this informant indicates that their parents gave them a lot of advices and these advices were most remembered by them through out their schooling experiences. These advices were motivations for them to study with the intention to improve the quality living of their family.

\begin{abstract}
"The one I remember most "If you want a good job, you have to study well" that's all I remember. When I hear their advice, I feel like to study well to improve my family." (Ido, Int 10: 26-27)
\end{abstract}

\title{
Authoritarian and Authoritative
}

The research data shows that three parents in this study adopted both authoritarian parenting and authoritative parenting styles based on the situation. They admit to scold their children for being stubborn but in a non-pressuring manner, smiling and being remindful.

"It's really hard to not scold. Just don't prolong it and keep it at heart. Sometimes there's not really much to be scold... Just scold a bit then show some support afterwards." (Neiry, Int 15:275-276, 278280)

"Something like scolding but in a gentle manner and give advices. Be gentle so that they are not scared. So that they will follow rules to learn. I never resort to caning because I once too fail. Caning hurts. Just keep them in our prayers so they will always be healthy and study hard." (Gulie, Int 19:25-26, 120-122, 124)

Data from children of this parenting style shows that they would still be punished if they made a mistake.

“...wanted to watch TV again tonight. So, I was chased, chased with a cane because I didn't want to come back home. They were afraid I couldn't get up for school, madam. Sometimes when we were already late for school, we didn't want to go. Haha" (Hijon, Int 16:40-42, 4547)

"If we had exams and there is a subject that I was weak in, my mother would scold and caned. Therefore, I would study hard." (Ryan, Int 20:30-31)

Other than that, the research data shows that informants of this study changed their parenting style based on the age of the child. When a child is young, especially towards sons, parents will practice the authoritarian parenting style but when the child reach adolescents, during secondary school, parents tend to adopt the authoritative style. They do not resort to strict disciplinary or punishments, instead, allowing the child to make their own decisions after being advised. 
DOI: https://doi.org/10.47405/mjssh.v6i6.830

"But if they're still in primary school I have to scold! Hahaha.. and if the boys were already secondary school I have to keep nagging.. like the one in matrik, my son." (Zenny, Int 11:58-60)

"I would ask them to study.. if it istime for them study, then study.. if not.. then sleep.. it's up to them.. as long as I've told them to study.. that's all. they're already in secondary school, they can think for themselves." (Zenny, Int 11:50-51, 54, 56)

"As parents. Or a father.. of course I worry. I'm like.. you know kids. When they're little, they don't think about their future. So I will tell them.. "I hope you won't regret one day.. because although our life is hard, but I'm willing to be in debts to spend on you as long you want to study" then they say "I don't regret, this is my decision" they said. Em "if that is so, you don't want to go to school, I cannot force you and hope for you to but help me around the farm" (Kinol, Int 13:136143)

Data from this informant also supports the change in their parenting style.

"Like me.. I've completed my SPM, my father asked me.. he said.. "do you want to further study?" (Prince, Int 12:43-44)

"My mother as well in terms of academic.. they.. they push but they don't like to force me.. unlike my younger siblings who are still little." (Peto, Int 6:109-110)

\section{Factors underlying the Parenting Style}

There are a few important factors underlying the parenting style. These factors are obtained from the analysed data.

\section{To end the hardship of life}

Majority of the parents involved in this study stated that the difficulties they are experiencing now motivates them to ensure their children do not inherit their hardships in the future.

"Moreover I don't want my children to be like me.. my life now is hard. Moreover I don't want my children to miss out on education.. I don't want them to follow my footsteps." (Jinam, Int 17:23-27)

"What i really did is what $i$ tell them "Study well, this is how us elders are, don't be like us". The purpose $i$ tell them like that is because i don't want them to one day to follow our footsteps and live a hard life like us.. that is why we have to tell so they won't have it hard one day. Even if you cant have, still be grateful even if it's a bad job, as long as it's not like us. (Sunny, Int 1: 73-76, 143-145)

"he he he...if it was me, just don't be like me that has no schooling, if it was me, in my heart. That is the reason I ask my children to go to school." (Gani, Int 7:166-168) 


\section{Awareness towards the Importance of Education}

The data also shows that the parents are aware that education could not be sold as physical property. For them, education is the only property they can give to their children for their future. The parents stated that a good education can change a life from hardships into a better one.

"That is why. education is very important.. these days.. an education background like ours.... it's hard.. hahaha because of these days, long ago.. my father told me. he said "if you have a garden, do gardening work". But now it's different.. even having a garden without an education is useless. Because today, everything has changed, so we are also chasing of the present. Tell the children to study hard.. because education is important.. If someone have a land of one acres.. but a bad conscience, they would sell the land. But if they have an education.. how would they sell? Until death, you will still have knowledge." (Rara, Int 9: 308-313)

"I want my children to succeed in education. If there is education, saya mahu anak-anak berjaya dalam pendidikan. kalau ada pendidikan, it means to continue living... to continue their life." (Matri, Int 3:180-183)

\section{Parents' hopes and expectation}

Parents practiced the parenting styles described above because of their high hopes of ending the had periods of their lives and change their living situation through education.

"ah.. if it was me, those who said they do not want to further their studies.. $i$ would be worried and angry. Because my purpose.. $i$ want to see them succeed in their education." (Matri, Int 3:49-50, 52)

"For me.. you know.. we are people who don't have anything, right? My don't have any education. Haha.. so I would like to be like the others.. something like a change in my life." (Jinam, Int 17:20-22)

\section{Challenged by Other's Opinion}

A data from one parent shows that they are motivated to send their children to school due to the frustration from the words of people around them which said about their family's poverty and their inability to afford sending their children to school. This causes them to be unhappy and motivates them to ensure their children go to school.

"At that time our life was very difficult. We didn't have a place. We had to stay in my uncle's house for a year. So, this uncle which we're talking about.. he said.. we have a lot of children. We have 9 of them. 7 boys, only 2 girls.. so, since that time, we had no income. Very tight at the moment. So he said.. "if they can school their children, it would be impressive. But looking at the situation, feedig them is already hard. Let alone schooling their children unless they sell their children." He said that. Ever since then I was very uneasy to hear that.. it hurts my feelings to hear people saying things like that. Therefore, I want to make more money so I can make sure my children go to school." (Kinol, Int 13:26-33, 39-40) 


\section{Discussion}

Based on the findings of the study, it is proven that two out of the three parenting styles mentioned in Baumrind (1966) theory can be seen to be practiced by the informants of this study. However, the most dominant parenting styles adopted to educate their children who now have succeeded in education is the authoritarian parenting styles, which gives children much control and instructions. This finding contradicts the findings of previous studies such as the findings of Rogers, Theule, Ryan, Adams, and Keaing (2009) in Canada which found that parents who practiced the authoritarian style contributed to student's low academic achievement. A study by Mohammed, Koorosh and Hamid (2011) in Iran also shows that the authoritarian style has a negative impact on children's academic achievement. The findings are further proven by the study of Odongo, Aloka and Raburu (2016) who also agree that the authoritarian style has a very low contribution to the children's academic achievements in Kenya.

However, there are also studies that show the positive impact of authoritarian style on student's academic achievement (Gonzalez, Greenwood \& WhenHsu, 2001). In this study, the effectiveness of the authoritarian parenting style is due to the informants' desire to end the hardships that they are experiencing over the years. They have come to the realization that the only way to change their lives is through education. Boon (2007) also agrees that academic success is believed to improve the way of life and determine success in the future. Therefore, because of this desire and awareness, the informants of this research ensure that their children succeed in education by practicing the authoritarian parenting style. The informants, who are children of this parenting style are also successful in their education as they realise their parents' actions are for the sake of their own future. Recent study by Juan Yang and Xinhui Zhoa (2020) also showed that the parenting style of Chinese parents which is predominantly authoritarian has impact on student's academic achievement.

Another practice of parenting style that is clearly proven is the changing of parenting style according to the age of the child. When the child is in primary school, the authoritarian parenting style is adopted; as the child grows to secondary school, the parents adopted the authoritative style. This indicates that parents practice the authoritarian style to shape the development of the child when they are still young. Then as the child grows older, they adopted the authoritative parenting style. They do not want to be too harsh against their teenage children and consider their feelings as they realise studying is not easy and they do not wish their children to fail because they themselves has experienced failures in life. Although the informants in this study did not have a higher education background and most did not attend school during their youth yet they possess a natural knowledge in terms of children psychology. The changing in parenting style indicates that the parents are aware that the children's needs changes as they grow and they have to adapt their parenting style to cater to the children's needs as that suggested by Shamah (2011).

The authoritative style that has been proven in many literatures as the best parenting style in relationships and its positive influence on students' academic achievements is only practiced by two informants. They practiced this parenting style because they believe that if a child is too stressed, they will not be able to understand what they are learning. The practice of the authoritative parenting style encourages children to develop self-confidence which is then interpreted as their confidence in their ability to succeed in their education. As cited by River (2008), based on her theoretical framework of parenting styles, Baumrind proposed that children of authoritative parents had stronger beliefs in their own efficacy or competence when faced with the challenges of academic tasks. These children possess good self-efficacy. The finding of this study is resemblance to the study by Somashekar, Chandrashekarappa, and Chandana (2019) which found out that the most preferred parenting style in the rural community was authoritative (63.2\%) followed by authoritarian $(26.2 \%)$ and permissive $(10.6 \%)$ types. 


\section{Conclusion}

In the cases of the parents in this study, who lived in rural areas, worked as farmers and wives as house wives, did not have an educational background, their parenting style is more of an authoritarian parenting style in educating their children and it is obvious that this has succeeded to bear the outcome of children who have excel in education. In the future, the same study may be conducted on the KadazanDusun parents using different methodologies to reinforce the findings of this study, or, to be conducted on different ethnic groups to see the similarities and differences as compared to that of this study.

\section{References}

Abar, B., Carter, K.L., \& Winsler, A. (2009). The effects of maternal parenting style and religious commitment on self-regulation, academic achievement, and risk behavior among AfricanAmerican parochial college students. Journal of adolescence, 32(2): 259-273

Baumrind, D. (1966). Effects of Authoritative Parental Control on Child Behavior, Child Development, 37(4), 887-907. doi: 10.2307/1126611.

Baumrind, D. (1971). Current patterns of parental authority. Developmental Psychology

Monographs. 4(1, Pt.2) 1-103.

Baumrind, D. (1991). Parenting styles and adolescent development. Journal of Early Adolescence, 11(1), 56-95. doi: 10.1177/0272431691111004

Berg, B. (2011). The effects of parenting styles on a preschool aged child's social emotional development. The Graduate School, University of Winsconsin-Stout. Retrieved from http://www2.uwstout.edu/ content/lib/thesis/2011/2011bergb.pdf.

Boon, J.H. (2007). Low and high achieving Australian Secondary school students: Their parenting, motivations and academic achievement. Australian Psychological Society, 42, 212-225.

Chan, T. W., \& Koo, A. (2011). Parenting Style and Youth Outcomes in the UK. European Sociological Review, 27(3), 385-399. ISSN: 0266-7215. doi: 10.1093/esr/jcq013

Chong, C. H. \& Yeo, K. J. (2018). The Residue Effects of Parental Corporal Punishment on Young Adults' Psychological Adjustment: Evidence From Malaysia. SAGE Open,1, 1-11.

Gonzalez, A., Greenwood, G. \& Wen Hsu, J. (2001). Undergraduate students' goal orientations and their relationship to perceived parenting styles. College Student Journal, 35(2), 182-192.

Ismail, K. H., Lukman, Z. M. \& Hamsan, H. H. (2008). Pembangunan kanak-kanak: teori, isu dan cabaran. Selangor: Arah Publication Sdn. Bhd.

Kosterelioglu, I. (2018). Effects of Parenting Style on Students' Achievement Goal Orientation: A Study on High School Students. Educational Policy Analysis and Strategic Research, 13(4), 91107. doi: 10.29329/epasr.2018.178.5

Lavric, M. \& Naterer, A. (2020). The power of authoritative parenting: A cross-national study of effects of exposure to different parenting styles on life satisfaction. Children and Youth Services Review, 116, 1-9.

Lazar, A., Guttmann, J., \& Abas, L. (2009). Parental authority in divorced families. Journal of Divorce \& Remarriage, 50(5), 356-368.

Leon-del-Barco, B., Mendo-Lazaro, S., Gallego, S. I., Polo-del-Rio, M. I. \& Gallego, D. I. (2019). Academic Goals and Parental Control in Primary School Children. International Journal of Environment Research and Public Health, 17, 206.

Maccoby, E. E., \& Martin, J. A. (1983). Socialization in the context of the family: Parent-child interaction. In P. H. Mussen (Ed.) \& E. M. Hetherington (Vol. Ed.), Handbook of child psychology: Vol. 4. Socialization, personality, and social development (4th ed., pp. 1-101). New York: Wiley.

Mohammad, A. B., Koorosh, A., Hamid, P. (2011). The relationship between parenting styles and children's academic achievement in a sample of Iranian families. Procedia Social and Behavioral Sciences 15, 1280-1283.

Mohd. Fauzi, M. H., Nor Aini, H. I., Madeline, B. \& Faridah, S. (2006). Kemiskinan di Kalangan Masyarakat Orang Asli. Jurnal Ekonomi Malaysia, 40, 95-101. 
Monika, R. S., \& Asudani, V. H. (2013). Parenting Styles \& Their Impact on Educational Performance of Children at High School Level: Review of Literature. Indian Streams Research Journal, 3(7), Retrieved from: http://isrj.org/UploadedData/2809.pdf

Moon, U. J. \& Bouchey, H. A. (2017). Effects of perceived parents' and teachers' values and beliefs on rural adolescents' college plans. The Social Science Journal, 56(4), 458-469.

Odongo. A.A., Aloka, P.J.O., and Raburu, P., (2016) Influence of Parenting Styles on the Adolescent Students'Academic Achievement in Kenyan Day Secondary Schools. Journal of Education and Practice, 7(15).

Othman, S. A., Azman, N. \& Mohd Ali, M. (2008). Faktor IbuBapa Dalam Kecemerlangan Akademik Pelajar Pekak: Kajian Kes Retrospektif, Malaysian Journal of Learning and Instruction, 5, 7998.

Razali, A., \& Razali, N. A. (2013). Parent-Child Communication and Self Concept among Malays Adolescence, 9(11), 189-200. doi:10.5539/ass.v9n11p189

Rivers, J. (2008). The Relationship Between Parenting Style and Acadmic Achievement and the Mediating Influences of Motivation, Goal-Orientation and Academic Self-Efficacy. The Florida State Educational Policy Analysis and Strategic Research, 13(4).

Rogers, M.A., Theule, J., Ryan, B.A., Adams, G.R. \& Keating, L. (2009). 'Parental involvement and children's school achievement: Evidence for mediating processes'. Canadian Journal of School Psychology, 24(1), 34-57.

Yasmin, S. \& Kiani, A. (2015). Role of Parenting Styles In Academic Performance Of College Students. Retrieved from https://www.researchgate.net/publication/332543580

Santrock, J. W. (2004). Life span development. McGraw-Hill, New York.

Shamah, R. M. (2011). Parenting Children of Different Ages: Adjusting Child Rearing Practices (Doctoral dissertation). Retrieved from https://digitalcommons.pace.edu/dissertations/AAI3451585/

Woolfolk A. (1995). Educational Psychology, 6th edition. USA: Allyn and Bacon.

Yahaya, A., \&Latif, J, S. (2005). MembentukIdentitiRemaja. Pahang: PTS Publications \& Distributions Sdn Bhd

Yang, J. \& Zhao, X. (2020). Parenting styles and children's academic performance: Evidence from middle schools in China. Children and Youth Services Review, 113, 1-12.

Zhang, H., Qin, X. \& Zhou, J. (2020). Do tiger moms raise superior kids? The impact of parenting styles on adolescent human capital formation in China. China Economic Review, 63, 1-21.

Zupancic, M., Podlesek, A., \& Kavcic, T. (2004). Parental child care practices of Slovenian preschoolers' mothers and fathers: The family environment questionnaire. Horizons of Psychology, 13(3), 7-26. 